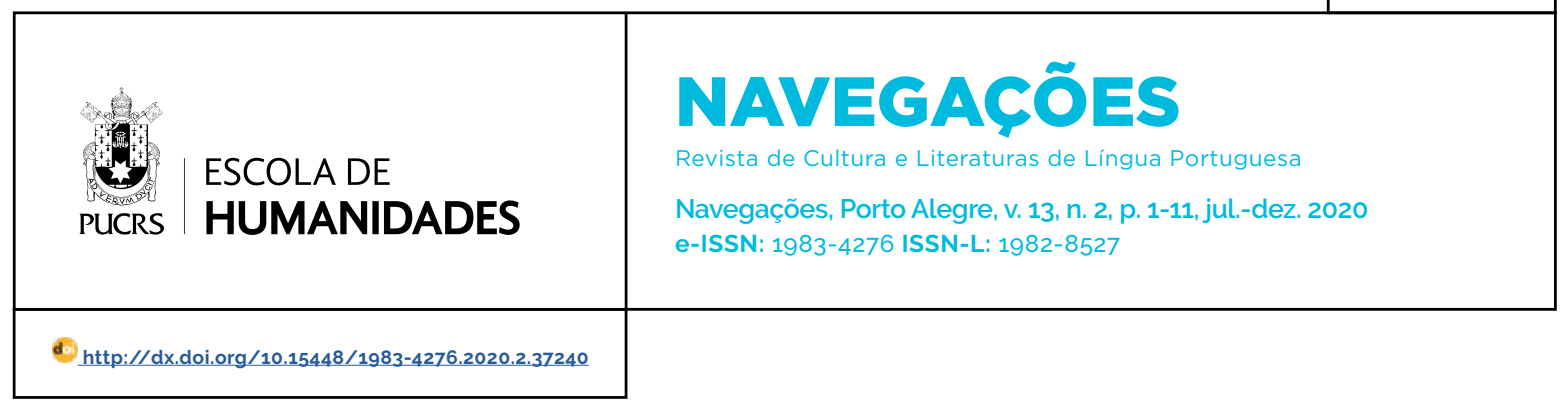

ENSAIOS

\title{
A representação de Angola na construção das personagens em Se o passado não tivesse asas, de Pepetela
}

The representation of Angola in the construction of the characters of Se o passado não tivesse asas, by Pepetela

\section{Ana Maria Coelho Silva Wertheimer ${ }^{1}$ \\ orcid.org/0000-0002-0987-2599 \\ ana.wertheimer@pucrs.br}

Recebido em: 6/3/2020

Aprovado em: 2/6/2020.

Publicado em: 25/2/2021

\section{(c) (1)}

Artigo está licenciado sob forma de uma licença Creative Commons Atribuicãa 4.0 Internacional.
Resumo: O presente artigo tem por objetivo analisar a construção das personagens do romance de Pepetela Se o passado não tivesse asas, que narra os tempos de guerra civil e de pós-guerra em Angola, um período entre 1995 e 2012. A luz de conceitos como exterioridade e excedente da visão, postulados por Mikhail Bakhtin, investiga-se como duas narrativas aparentemente independentes, que apresentam protagonistas supostamente distintas (Himba e Sofia), são capazes de descrever metafórica e criticamente o processo de reconstrução do país. Por meio do olhar do narrador heterodiegético, é possivel estabelecer-se uma relação entre o eu e o outro em dois planos que se interligam: um plano temporal (a trajetória das duas personagens) e um plano espacial (o olhar do outro que observa de uma posição externa e que, por isso, pode identificar o que excede). O discurso não finalizável sugerido por Bakhtin revela o que parece ser a proposta dos textos literários de Pepetela a partir de 1990: denunciar a tentativa de Angola de apagar o passado.

Palavras-chave: Pepetela. Se o passado não tivesse asas. Mikhail Bakhtin. Construção da personagem.

Abstract: This article aims to analyze the construction of the characters of Pepetela's novel Se o passado não tivesse asas (If the past had no wings, free translation), which narrates the time of the civil war and post-war in Angola, a period between 1995 and 2012. In the light of concepts such as exteriority and the surplus of vision, proposed by Mikhail Bakhtin, we examine the way two apparently independent stories, which supposedly present two different main characters (Himba and Sofia), manage to describe, metaphorically and critically, the process of the reconstruction of Angola. Through the eyes of a heterodiegetic narrator, it is possible to establish a self-Other relation in two interconnected levels: a temporal level (the characters' journey) and a spatial level (the eyes of the Other that observes from an external position and, therefore, is able to identify what exceeds). The nonfinalizable discourse suggested by Bakhtin reveals what seems to be the proposal of Pepetela's literary texts from 1990 onwards: to report the attempt of Angola to erase the past.

Keywords: Pepetela. Se o passado não tivesse asas. Mikhail Bakhtin. Construction of the character.

\section{Introdução}

A análise do romance Se o passado não tivesse asas, publicado em 2016 pelo conhecido escritor angolano Pepetela, revela aspectos históricos e culturais de um país que, após a guerra anticolonial encerrada em 1974. enfrentou uma longa (e igualmente violenta) guerra civil até o ano de 2002. Sem constituir uma escrita panfletária, a ficção de Pepetela tem por 
tema a construção da identidade de Angola e a (re) visão de sua história. Nas palavras da professora de Literaturas Africanas em Lingua Portuguesa da Universidade federal do Rio de Janeiro (UFRJ) Carmen Lucia Tindó Ribeiro Secco (2009), a produção literária deste escritor caracteriza-se "por um constante e lúcido olhar sobre a história de Angola" (SECCO, 2009, p. 151), por meio de "estratégias narrativas que conjugam elementos da modernidade e da tradição, recuperando dessa última os aspectos culturais fundamentais" (SECCO, 2009, p. 151). O próprio escritor reconhece uma dimensão histórica e ideológica em sua escrita:

Tenho uma grande preocupação com alguns assuntos, que são temas obsessivamente tratados na minha obra. Um desses assuntos é o da construção da Nação, a ideia de Nação. Há toda uma problemática à volta do Estado-Nação, particularmente em África. [...] Ora, a História ajuda a enquadrar este problema e talvez até tenha algumas respostas. [...] E nesse caso pode dizer-se que é ideológico considerar-se o passado como fonte de conhecimento do presente (PEPETELA, 1999, p. 114).

Para Agualusa, escritor conterrâneo de Pepetela, é papel da literatura manter viva a memória de guerra em países como Angola e Moçambique e denunciar as opressões e violências sofridas: "a literatura deve ser um lugar, um espaço, um território de debate, um território de pensamento, um território de ideias" (AGUALUSA, 2013, p. 103). Essa possivel (e proficua) relação entre história e ficção em metaficções historiográficas contribuem, segundo Linda Hutcheon (1988), para evidenciar um contexto histórico "tanto quanto qualquer argumento teórico" (HUTCHEON, 188, p. 135). Para essa autora,

Assim como a literatura, a arquitetura e as artes visuais pós-modernas precisam lutar contra as tentativas do modernismo no sentido de ficar fora da história - por meio da pura forma, do abstracionismo ou do mito - ou de controlá-la por meio de modelos teóricos de fechamento. Na ficção pós-moderna, o literário e o historio- gráfico são sempre reunidos - e normalmente com resultados desestabilizadores, para não dizer desconcertantes (HUTCHEON, 1988, p. 136, grifo da autora).

Nos romances escritos após 1990, entretanto, Pepetela acrescenta aos temas de relativos à identidade e à história a ideia de angolanidade. Pelo viés das distopias sociais, o escritor alerta para "a crise que destruiu o país [...] mostrando que as guerrilhas entre a UNITA e o MPLA² [no pós-guerra] dilaceraram ainda mais a nação" (SECCO, 2009, p. 154).

No romance Se o passado não tivesse asas, dois momentos distintos da história de Angola são representados: o ano de 1995, em meio à guerra civil, e o ano de 2012, quando Angola celebra dez anos de paz. A história dos amigos Himba e Kassule, órfãos de guerra e entregues à própria sorte nas ruas da capital angolana, passa-se em 1995: simultaneamente, o narrador conta a história dos irmãos Sofia e Diego - este, um artista plástico, cuja arte expressa a cultura do povo angolano, e aquela, uma ambiciosa sócia-proprietária de um restaurante em ascensão. Ao intercalar duas histórias, aparentemente autônomas, o escritor evidencia o crescimento econômico de um país em reconstrução, porém ainda marcado pela desigualdade social e violência. Jorge Valentim, professor da Universidade Federal de São Carlos, explica o momento pós-guerra:

Longe de ser uma prorrogativa do domínio colonial português ou um privilégio dos idos anos de furor salazarista, parece mesmo que a sobrevivência na guerra civil e no periodo que a ela se sucede, os atos de violência não só teimam em sobreviver, mas também deixam uma herança quase que irrevogável: a corrupção, a especulação, o consumismo desenfreado, a perda de valores éticos e morais, o nepotismo, o interesse desmedido, além de outras vicissitudes que bem poderiam engrossar a lista (VALENTIM, 2009, p. 348).

\footnotetext{
2 Segundo Oliveira (2015, p. 32), uma das consequências da primeira guerra pós-colonial (1975-1991) foi a tomada de Angola por dois partidos que lutavam pelo controle da nação, a saber, a União Nacional para a Independência Total de Angola (UNITA) e o Movimento Popular de Libertação de Angola (MPLA). "O MPLA foi criado por jovens angolanos assimilados e mestiços, primeiro no exílio e depois em Luanda. Inspirados pela oposição de esquerda em Portugal e pelas tendências anticolonialistas da época, o MPLA constitui-se como um movimento de libertação moderno e inclusivo" (OLIVEIRA, 2015, p. 30). O autor revela, porém, que por trás desse discurso democrático "escondia-se o desejo de poder [político] de uma elite social" (OLIVEIRA, 2015, p. 30). Em contrapartida, a UNITA constituía uma facção rebelde, fundada por Jonas Savimbi, um lider carismático, inteligente e violento, que "preconizou uma ideologia totalmente situacionista, em função da qual se aliou ora com os portugueses, ora com a China, a África do Sul do apartheid, a administração Reagan e diversas forças democratas-cristãs europeias, entre outros" (OLIVEIRA, 2015. p. 35).
} 
Em Se o passado não tivesse asas, a "herança da guerra" de que fala Valentim - a desigualdade social, a corrupção e a perda de valores éticos e morais - está representada no contraste das personagens Himba e Sofia. Na tentativa de apagar o passado de miséria e violência, a menina que, após ter sua família dizimada na guerra civil, passar fome e ser violentada em mais de uma ocasião, assume uma nova identidade semelhante, em muitos aspectos, à de seus opressores da infância na guerra. É pelo olhar do amigo/irmão e pela voz do narrador heterodiegético que se revela a transformação por que passa a protagonista e, de forma análoga, a transformação do próprio país angolano.

Para desenvolver a análise da construção das duas personagens, propõe-se uma relação entre o eu e o outro em dois planos distintos: em um plano temporal (a trajetória da personagem Himba/Sofia e as relações entre o passado e o presente) e em um plano espacial (a conjuntura do pós-guerra pelo olhar do narrador, aquele que observa de uma posição externa e que, por isso, pode identificar o que excede, uma totalidade percebida por ângulos aos quais a personagem não tem acesso). Acredita-se que, pelo excedente da visão, tema proposto pelo o teórico russo Mikhail Bakhtin (1895-1975), seja possivel explicar as representações de Himba e Sofia no que tange Angola durante e após o periodo de guerra.

\section{Exterioridade na obra Literária}

O conceito de exterioridade está no cerne das reflexões de Bakhtin acerca do dialogismo. Segundo Caryl Emerson (2003), uma estudiosa das teorias bakhtinianas, "a necessária 'exterioridade' de uma pessoa em relação a outra" (EMERSON, 2003, p. 252, grifo da autora) é a condição que torna possivel a uma obra de arte satisfazer os quatro critérios que governam todo evento criativo, a saber: a obra deve ser singular, responsiva, participatória e "assumida com um 'espírito estético'" (EMERSON, 2003, p. 253, grifo da autora). Por responsiva, entende-se que a obra tem uma autoria, ou seja, é "'assinada' por seu autor ou beneficiário, responsável" (EMERSON, 2003. p. 253, grifo da autora); por participatória, assume-se que toda criação artística, na perspectiva bakhtiniana, é orientada para uma outra consciência, ou, em outras palavras, constitui um diálogo entre o eu e o outro que se realiza "no presente do processo artístico" (BAKHTIN, 2015. p. 71). Para Morson e Emerson (2008),

\begin{abstract}
o ouvinte (real ou imaginado) molda o enunciado desde o principio. Em contraste com a teoria da recepção pelo leitor, que usualmente se ocupa do modo pelo qual este interpreta os textos depois que são produzidos, o modelo dialógico de Bakhtin representa os leitores como moldando o enunciado enquanto ele está sendo feito (MORSON; EMERSON, 2008, p. 144-145, grifo dos autores).
\end{abstract}

É compreensivel, portanto, que o termo diálogo em Bakhtin corresponda a um processo contínuo de comunicação que se caracteriza como uma atividade inacabada ou não finalizável, que "envolve a redefinição constante dos seus participantes, desenvolve e cria numerosos potenciais 'em' cada um deles 'separadamente' e entre eles 'interativamente' e 'dialogicamente'" (MORSON; EMERSON, 2008, p. 70-71, grifos dos autores).

Para Bakhtin, a arte era uma ativa co-criação de imagens que serviam para ligar "responsivamente" uma personalidade individual a uma realidade imediata. Como tal, a arte postulava uma espécie de "ativismo estético" inteiramente novo para as tradições da intelligentsia russa, que tendia a desconsiderar as interações positivas e pragmáticas entre pessoas reais em favor de projeções utópicas e descontinuidades abruptas (EMERSON, 2003, p. 254. grifo da autora).

No diálogo entre o eu e o outro, o conceito bakhtiniano de exterioridade refere-se menos à distância ou ao isolamento, mas antes a uma posição externa de onde o outro é capaz de ver aquilo a que o eu não tem acesso e vice-versa. "É claro que diferentes gêneros, estilos e meios de comunicação demandam dos autores graus diversos de exterioridade [...] mas um autor sempre desfruta de um certo excedente de visão em relação a outra consciência potencial numa obra de arte; é isso o que faz da arte uma relação 'eu-outro'" (EMER- 
SON, 2003, p. 254, grifos da autora).. "A totalidade de qualquer coisa só pode ser observada de uma posição que lhe é exterior no espaço e posterior no tempo" (EMERSON, 2003, p. 267).

Cabe aqui um esclarecimento sobre o uso do termo autor nos estudos de Bakhtin. O teórico diferencia o autor real das figuras do autor e do narrador de histórias. Ao discorrer sobre o plurilinguismo, Bakhtin refere-se ao autor como aquele que conta uma história escrita e ao narrador como o que conta uma história oral. Diz o teórico:

Essa forma humoristica de introdução e organização do plurilinguismo no romance é essencialmente diferente do conjunto das formas que são definidas pela introdução de um suposto autor personificado e concreto (palavra escrita) ou de um narrador (palavra oral). [...] este distanciamento em que se encontram o autor ou o narrador supostos em relação ao autor real e à perspectiva literária normal pode ser de grau e de caráter diferentes (BAKHTIN, 1988, p. 117).

Na conclusão do ensaio Forms of time and the chronotope, que foi adicionada à obra original de apenas 35 anos mais tarde, em 19734. Bakhtin diferencia o autor-criador da obra do autor ser humano e adverte,

Nunca devemos esquecer isso, nunca devemos confundir - como foi feito até agora e ainda é feito - o mundo representado com o mundo fora do texto (realismo ingênuo); nem devemos confundir o autor criador de uma obra com o autor como um ser humano (biografia ingênua) [...] Todas essas confusões são metodologicamente inadmissiveis (BAKHTIN, 1981, p. 253. grifo do autor, tradução nossa) 5 .

É por meio do excedente de visão, portanto, que o narrador constrói a personagem na obra literária. Morson e Emerson, estudiosos das teorias bakhtinianas, afirmam que "o excedente de um autor finaliza a personagem e estabelece definitivamente sua identidade" (MORSON; EMERSON, 2008, p. 70-71, grifo dos autores).

Por outro lado, o estatuto de uma obra polifônica renuncia ao excedente essencial, isto é, ao conhecimento e à revelação de fatos não-disponiveis para a personagem, como sua psicologia e seu destino. Para Bakhtin, Dostoiévski, "o criador da autêntica polifonia" (BAKHTIN, 2015, p. 39), é capaz de produzir um discurso não finalizável que se orienta por uma visão que excede o olhar da personagem, porém não lhe explicita todos os acontecimentos exteriores no espaço e posteriores no tempo. Segundo Morson e Emerson, Dostoiévski tem o mérito de construir personagens dialógicas ou inacabadas, que se realizam no presente de um processo contínuo de comunicação: o seu "grande feito [...] foi descobrir um modo de encontrar as suas personagens tão não-finalizáveis como outros e envolvê-las num genuíno diálogo aberto-acabado" (MORSON; EMERSON, 2008, p. 257).

Trata-se, na perspectiva bakhtiniana, de uma nova posição do autor/narrador: no romance polifônico o autor conserva uma relativa liberdade e independência das personagens ao renunciar o excedente essencial (um campo de visão da totalidade) e ao reservar para si "apenas o mínimo indispensável do excedente pragmático, puramente informativo, que é necessário à condução da narração" (BAKHTIN, 2015, p. 83, grifo do autor). O autor/narrador polifônico, como afirmam Morson e Emerson,

\begin{abstract}
cria o mundo no qual a personagem não-finalizável vive e com isso pode introduzir encontros casuais e incidentes provocativos. [...] Como participante do diálogo com a personagem, o autor tem à sua disposição quase toda a série de interações dialógicas. Pode provocar e importunar a personagem, lisonjeá-la e afagá-la, irritá-la e insultá-la. [...] O autor polifônico, em suma, desempenha necessariamente dois papéis na obra: cria um mundo no qual muitos pontos de vista dispares entram em diálogo e, num papel muito distinto, ele próprio participa deste diálogo (MORSON; EMERSON, 2008, p. 255, 257-258).
\end{abstract}

Vale ressaltar que, ao refletir sobre a exterioridade do autor em relação a sua obra - ou a um excedente de visão mínimo (e necessário) para o

\footnotetext{
3 As ideias de excedente reciproco, de exterioridade e de suplementaridade, segundo Emerson (2003, p. 252), constam já nos primeiros escritos filosóficos de Bakhtin, produzidos ainda na década de 20 do século passado.

4 A informação sobre o acréscimo da conclusão à obra Forms of time and the chronotope, de 1937-1938, consta em BEATON, 2015, p. 82. 5 Do original: We must never forget this, we must never confuse - as has been done up to now and as is still often done - the represented world with the world outside the text (naive realism); nor must we confuse the author-creator of a work with the author as a human being (naïve biographism) [...] All such confusions are methodologically impermissible.
} 
processo de criação de uma narrativa ${ }^{6}$-, Bakhtin propõe um modelo tripartite do eu, a saber, o eu-para-mim-mesmo (a consciência do eu por e para si mesmo), o eu-para-o-outro (a visão do outro em relação a mim) e o outro-para-mim (a minha visão em relação ao outro). A análise da construção das personagens e da identidade da sociedade angolana por meio do romance Se o passado não tivesse asas, proposta deste trabatho, quer seja em um em um plano temporal ou espacial, leva em conta a relação do eu-para-o-outro, isto é, o modo como as experiências das personagens (o eu) dialogam e se completam "de fora", por um olhar exterior (o olhar do outro) que excede a visão do eu.

\section{Excedente no plano temporal}

No plano temporal, a referência ao passado está expressa em várias partes da narrativa, a começar pelo título, Se o passado não tivesse asas: uma oração subordinada condicional que se apresenta sem uma oração principal, ou seja, em um periodo incompleto. O título, portanto, por si só, já estabelece um diálogo, pois transfere ao interlocutor a tarefa de finalizá-lo. Se o passado não tivesse asas pressupõe que o passado esteja esquecido e esse apagamento é representado na trajetória das personagens Himba e Sofia.

Para o professor de Política Comparada da Universidade de Oxford Ricardo Soares de Oliveira (2015), "os angolanos revelam-se, por vezes, dispostos a seguir a máxima de Ernest Renan, para quem uma nação se define tanto pelo esquecimento coletivo, e até pelo erro histórico, como pela memória" (OLIVEIRA, 2015, p. 155). O professor também justifica o interesse desse apagamento por parte do governo angolano:
- MPLA gosta de avivar a memória dos angolanos sobre a brutalidade da UNITA e a "responsabilidade pela guerra" imputável a Savimbi, embora o faça sempre em termos imprecisos, não vá isso despertar uma curiosidade generalizada em relação ao historial das duas facções beligerantes. No que diz respeito a sua própria brutalidade, o MPLA denota uma amnésia quase total. Esta abrange a guerra civil (em especial o massacre de Luanda, em $1992^{7}$, e a deslocação maciça de populações nos últimos anos do conflito) [...] (OLIVEIRA, 2015, p. 155, grifo do autor).

Ao tentar fugir para a capital angolana em meio à guerra civil, no ano de 1995, a família de Himba é dizimada e a menina segue sozinha a Luanda onde tem de lutar para sobreviver. Filha de pai professor e mãe enfermeira, Himba, a mais velha de cinco filhos, demonstra sua força e coragem já nos primeiros parágrafos da história. Ao descrever o pai, "homem sem jeito para trabalhos manuais" que "gostava só de ler e ensinar" (PEPETELA, 2017, p. 11), o narrador legitima a sensibilidade e inteligência de Himba que, com treze anos recém feitos, já concluíra a terceira classe. Pelo olhar do pai, sabe-se que Himba "talvez fosse demasiado adulta, tinha muito sentido de responsabilidade [...] sempre ocupada a tomar conta dos irmãos e a aprender a lida da casa com a mãe ou os deveres da escola" (PEPETELA, 2017, p. 12). Pelo olhar mais pragmático da mãe, compreende-se que "uma situação de guerra afeta as crianças tanto ou mais que os adultos [...] Uns são mais sensiveis que outros, uns mais virados para dentro" (PEPETELA, 2017, p. 12).

Sem saber se seus pais e irmãos haviam sobrevivido ao ataque, Himba viaja para Luanda com a ajuda de soldados que encontra na estrada. Nessa primeira parte da história, já há pelo menos uma referência à identidade do povo angolano. Por delicadeza, Himba oferece uma maçã ao motorista do caminhão militar que a levaria a Luanda.

\footnotetext{
6 Ainda que as histórias possam ser narradas no tempo presente, toda narração é "posterior àquilo que conta" (GENETTE, 1995, p. 215). Cabe ao escritor a escolha do tempo verbal (pretérito ou presente), o que, segundo Genette (1995), pode gerar efeitos distintos: o emprego do pretérito separa o momento narração do momento da história "sem por isso indicar uma distância temporal" (GENETTE, 1995 p. 219); ao passo que o uso do tempo presente com valor de passado, ou mesmo de futuro, tende a aproximar o ato de narrar da história narrada, atribuindo a esta uma relativa contemporaneidade.

7 Oliveira (2015, p. 38) explica os motivos que incitaram o massacre de Luanda: na eleição presidencial de setembro de 1992, embora o candidato do MPLA tenha recebido mais votos ao, Savimbi, lider do UNITA, recebeu um número expressivo de votos o que exigiu a realização de uma segunda eleição, que nunca ocorreu. "Na véspera do Dia de Todos-os-Santos, após várias semanas de grande tensão, Luanda foi varrida por uma onda de violência. Apoiado nas suas milícias de poder popular, fortemente armadas, e no corpo de Polícia de Intervenção rápida, treinado pelos espanhóis, o MPLA moveu uma terrivel perseguição aos militares e quadros dirigentes da UNITA que haviam permanecido na cidade. Milhares de pessoas [...] foram massacradas em apenas três dias. (OLIVEIRA, 2015, p. 38).
} 
O cabo recusa a oferta por ter consciência de que o alimento fará falta para a menina. Entretanto, uma senhora que segue para Luanda no mesmo caminhão pede a fruta à Himba "que não estava educada para chocar contra a vontade de um mais-velho" (PEPETELA, 2017, p. 19). O cabo percebe a situação e cantarola "oportunismos, oportunismos, oh, oh, os oportunismos desta terra são mais fortes que a guerra" (PEPETELA, 2017, p. 19).

O narrador heterodiegético antecipa aquela que será a atitude da protagonista no decorrer da história (e que representa, de forma alegórica, a postura da própria sociedade angolana): uma tentativa de apagamento do passado. Ao informar sobre a partida de Himba para Luanda, o narrador faz sugestões acerca do futuro da personagem: "O caminhão partiu e a menina fez adeus grato ao sargento e ao quartel e ao passado, sem querer pensar realmente nisso, ia só procurar os pais e irmãos lá à frente. Nem fazia ideia do que ia encontrar" (PEPETELA, 2017, p. 18).

A história de Himba em Luanda assemelha-se a de outros órfãos de guerra que dormem nas ruas da capital angolana e alimentam-se de restos de comida descartados no lixo. Himba conhece Kassule, um menino mais novo, para quem a guerra civil deixou, além de marcas psíquicas, uma marca física irreversivel: falta-lhe uma das pernas devido à explosão de uma mina terrestre. Juntos, os dois amigos compartilham seus sofrimentos e enfrentam situações de violência e abusos sexuais. Himba é estuprada por um grupo de meninos, como havia previsto e alertado uma menina mais velha chamada Madia, conhecedora dos perigos da vida nas ruas de Luanda.

Após ter sido violentada em frente a Kassule, Himba

demorou a parar de chorar mas acabou por ganhar forças e, apoiada pelo amigo, caminhou para fora da floresta e dos seus monstros gargalhando entre os ramos e as folhagens. Tudo the doía mas o pior não era a dor física. Se sentia roubada [...] Vergonha, medo, e lá no fundo, uma tremenda revolta, inconfessável (PEPETELA, 2017, p. 89).

No discurso do narrador heterodiegético, que possui a visão do excedente, identifica-se o so- frimento e a reação da personagem ("caminhou para fora da floresta e dos seus monstros gargalhando"). O olhar exterior do narrador revela os sentimentos de vergonha, medo e revolta de Himba, que serão determinantes para suas atitudes no futuro, em especial, para a sua decisão de esquecer o passado. O silêncio de Himba é percebido pelo amigo Kassule:

\begin{abstract}
Riam todos, menos Himba, sempre fechada dentro dela. Kassule reparava e calava rápido os risos dele. Himba agora andava descalça, as sandálias tinham ficado perdidas na floresta. Os pés não estavam habituados ao cimento quente ou à areia de cima da praia, igualmente a queimar quando o sol batia furioso. Só mesmo a areia da noite ou a da beira da água eram suportáveis. Não pensava no que the tinha acontecido, varria a memória com a mão aberta, como se pudesse. (PEPETELA, 2017, p. 100).
\end{abstract}

As circunstâncias parecem modificar o comportamento de Himba que, depois de duas semanas do violento estupro (e da consequente perda dos chinelos), "escapla] de cometer um crime" (PEPETELA, 2017, p. 125): o roubo de um par de chinelos na beira da praia. Kassule, por sua visão de excedente e por seus princípios morais e éticos, impede a personagem de concretizar o ato:

\begin{abstract}
Kassule adivinhou o pensamento, porque viu o olhar famélico de Himba. Ela se encaminhava para as roupas, quando ele disse baixo, de modo que a arrebentação e a distância cobrissem a voz:

- Como vou fugir se elas virem?

Fácil de identificar. Himba se desviou logo das coisas, continuou a caminhar. Ela não falou, ele não perguntou. Mas sabia, a amiga ia mesmo cometer, os olhos não enganam (PEPETELA, 2017, p. 125).
\end{abstract}

Com o objetivo de "eliminar a ruptura entre o 'formalismo' e o 'ideologismo' abstratos no estudo do discurso literário" (BAKHTIN, 1988, p. 71), Bakhtin analisa o discurso do gênero romanesco como um fenômeno social cujos elementos forma e conteúdo não podem ser analisados separadamente. Como fenômeno social, o teórico defende o aspecto dialógico do discurso no romance e propõe uma alternativa para o estudo desse discurso por parte da estilistica e da filosofia: reconsiderar a base da estilística tradicional (ou 
seja, desassociar a obra romanesca dos limites do discurso poético) e recorrer à retórica para identificar a concepção do discurso em prosa.

Bakhtin (1988) vale-se do discurso retórico para legitimar o interlocutor (leitor ou ouvinte) como elemento fundamental e constitutivo do gênero: "De fato, para a retórica é efetivamente característico que a relação com o ouvinte concreto, o lugar ocupado por esse ouvinte, se integre na mesma estrutura externa do discurso retórico" (BAKHTIN, 1988, p. 89). O teórico argumenta que "toda compreensão é ativa" (1988, p. 90) e o escritor pressupõe uma resposta ou reação do ouvinte ainda no processo de criação da obra não finalizável. ${ }^{8}$ Bakhtin, portanto, aproxima-se da retórica para descrever as características do discurso na prosa: um discurso orientado para a compreensão ativa do ouvinte, o que determina sua dialogicidade interna.

No gênero romanesco, as ressonâncias dialógicas penetram em suas camadas mais profundas, tornado a própria língua dialógica pela concepção linguística de mundo (a forma interna do discurso). A prosa romanesca, concluem Morson e Emerson (2008), constitui-se de relações dialógicas encontradas "não primariamente nos 'diálogos expressos composicionalmente' entre as personagens, mas na heteroglóssia` hibridizada, bivocalizada, dialogizada, da própria voz do autor" (MORSON; EMERSON, 2008, p. 343, grifo dos autores).

Esse discurso dialogizado por ser identificado na voz da senhora Isabel Kimba, a única pessoa que se dispõe a oferecer ajuda aos protagonistas da primeira história. Ao falar sobre a morte do marido, no massacre de Luanda em 1992, o discurso da viúva deixa transparecer três aspectos da história da guerra civil angolana: a morte de pessoas comuns e apartidárias, a omissão da Igreja Católica e a insignificante questão sobre qual lado iniciou efetivamente o massacre.

\begin{abstract}
- Foi no sábado de manhã. Ele trabalhava na alfândega dos correios centrais. Como sabem, o correio fica entre o comando da polícia e o hotel que está todo esburacado de balas agora, ao pé da igreja da Conceição. Quase nenhum colega foi trabalhar, se sabia a guerra rebentava nesse dia ou no seguinte. Mas ele nunca faltava no serviço, ia e vinha a pé, ainda é um bocado longe. [...] Quando saiu do trabalho com um companheiro, disse, vou apreciar bem esse hotel que virou quartel da oposição armada, assim ele chamava, nunca os nomes dos partidos, dizia dava azar. Nomeava o partido do governo e o partido da oposição armada. [...] Não sei mesmo o que passou na cabeça dele, penso nisso e não posso encontrar explicação, ele sempre tão certo, pontual, calmo e prudente... Quando começaram os tiros, queria se refugiar dentro mas a porta da igreja estava fechada. Foi então morto. Por quem? Vá-se lá saber... Também não interessa, foi morto pela guerra, chega! (PEPETELA, 2017, p.127-128).
\end{abstract}

O olhar externo do interlocutor ratifica a pluralidade e dialogicidade interna do discurso do romance: o discurso permanece aberto para inferências em um "processo contínuo de comunicação" (MORSON; EMERSON, 2008, p. 254). As relações dialógicas abrangem, portanto, duas orientações distintas: o diálogo como resposta a dizeres anteriores ao próprio discurso (o já dito) e o diálogo como resposta a dizeres futuros (ao que ainda não foi dito). Para Bakhtin, apenas Adão, o primeiro dos homens, poderia evitar a orientação dialógica do discurso: "Apenas o Adão mítico que chegou com a primeira palavra num mundo virgem, ainda não desacreditado, somente este Adão podia realmente evitar por completo esta mútua-orientação dialógica do discurso alheio para o objeto" (BAKHTIN, 1988, p. 88).

Em busca de proteção, Himba e Kassule juntam-se ao grupo de Tobias, um garoto mais velho que trata a menina como sua esposa. Sob o consentimento dissimulado de Himba, o rapaz vinga-se de cada um dos meninos que a violentaram. O rapaz, porém, é assassinado e Himba, desprotegida, sofre um segundo estupro. Os dois

8 Enquanto na Estética da Recepção, no final da década de 1960, Hans Robert Jauss e seus colegas da Escola de Constança analisam a construção de sentido do texto já concebido, Bakhtin estuda o texto como um processo contínuo de comunicação, como uma obra polifônica na qual "várias consciências se encontram como iguais e entram num diálogo que em princípio é não-finalizável" (MORSON: EMERSON, 2008, p. 254). Bakhtin, em suma, estuda o papel do outro como aquele que orienta a criação obra literária no momento de sua produção ou no momento de sua leitura, também considerada como um processo criativo.

9 Os tradutores da versão em língua portuguesa de Questões de literatura e estética, a saber, Aurora Fornoni Bernardini, José Pereira Júnior, Augusto Góes Júnior, Helena Spryndis Nazário e Homero Freitas de Andrade, acrescentam uma nota, explicando que o termo russo é traduzido por "heteroglóssia", "pluridiscurso" ou "pluridiscursividade" e significa "o conjunto de linguagens diferentes que compõem o discurso do prosador-romancista" (BAKHTIN, 1988, p. 107) 
amigos recorrem à senhora Isabel que, entre conselhos como não fumar liamba nem cheirar gasolina, já havia oferecido a proteção de um padre em um abrigo para menores. É no abrigo que Himba e Kassule terminam seus estudos e o menino "deixa extravasar sua veia artística, desenhando atitudes, gestos ou detalhes da vida. Cada vez melhor" (PEPETELA, 2017, p. 283). Dentre os vários indicios que conectam a narrativa de 1995 com a narrativa de 2012, a habilidade artística de Kassule é reveladora e muito significativa para as duas histórias: ainda no abrigo, Kassule desenha um retrato de Himba (a relação eu-para-o-outro) e a personagem, em diferentes momentos, revê seu retrato como se se olhasse no espelho sob o ângulo do qual Kassule a enxerga.

Ela olhou e viu no papel o que achava ser verdadeiramente, ou o que parecia ser aos olhos de Kassule, coincidente. Estava numa atitude meditativa, contemplando o seu interior ou o seu passado, o que se notava no toque quase imperceptível do lábio inferior, que lhe fazia a boca assimétrica, e na profunda tristeza dos belos olhos (PEPETELA, 2017, p. 283).

Ao anúncio do final da guerra civil, no ano de 2002, foi criado um programa para o reencontro das famílias apartadas. Já prestes a concluir o curso médio de contabilidade, Himba, que não havia sido reconhecida por parente algum, decide retornar à terra natal a fim de saber sobre sua familia. Na cidade destruida pela guerra, a jovem é finalmente informada de que seus pais e irmãos morreram na explosão do caminhão e de que todos os documentos da família haviam sido queimados na guerra. Himba responsabiliza o pai pelo extermínio da familia e subitamente, em "uma espécie de revelação" (PEPETELA, 2017, p. 341), decide mudar de identidade. "De facto, queria se libertar do apelido paterno, talvez isso lhe fizesse esquecer o passado, toda a dor acumulada, partia para uma nova vida com novo nome. Sem o lastro de culpa do pai, a vergonha por ele, causador da tragédia da família (PEPETELA, 2017, p. 342).

Himba substitui o nome kimbo (de seu povoado) por um nome estrangeiro, Sofia, "como a irmã perdida de Kassule" (PEPETELA, 2017, p. 342) e registra-se como Sofia Moreira. Kassule é convencido pela amiga a fazer o mesmo e a mudar-se com ela para um apartamento alugado. Oficialmente reconhecidos como irmãos, Sofia e Diego deixam o abrigo com a promessa de "se ver muitas vezes" (PEPETELA, 2017, p. 347-348); entretanto, na tentativa de apagar o passado, a protagonista também renega aqueles que a apoiaram:

[...] Sofia nunca mais pôs o pé no lar e deixaram as missas de domingo. Diego aparecia de vez em quando para visitar os amigos e desculpar a irmã, anda sempre muito ocupada.

Todos sabiam, era mentira (PEPETELA, 2017, p. 347, 348).

Nesse ponto, já no final do livro, as duas narrativas se unem e percebe-se que a primeira, de certo modo, explica a segunda, ou seja, a ambição e os atos ilícitos de Sofia são justificados pelo sofrimento de Himba.

\section{Excedente no plano espacial}

Um dos aspectos essenciais do discurso do romance, referido por Bakhtin em um estudo que contrasta prosa e poesia, é a dialogicidade interna do discurso. Segundo o teórico, "o discurso nasce no diálogo como sua réplica viva, forma-se na mútua-orientação dialógica do discurso de outrem no interior do objeto" (BAKHTIN, 1988, p. 89).

A história que se passa em 2012, dez anos após o final da guerra civil de Angola, inicia-se com a mudança de endereço de Sofia e Diego, agora para um apartamento maior, ainda de aluguel. Diego estabeleceu-se como pintor, porém ainda busca realizar sua obra-prima: "os elementos se apresentavam pintados com realismo, o conjunto equilibrado, as cores corretas como lembrava de vidas anteriores ou tinha visto em livros e em filmes, os movimentos bem delineados, mas faltava a alma" (PEPETELA, 2017, p. 45). Pelos olhos de Diego, identifica-se como a arte africana é reconhecida pelos europeus:

\footnotetext{
De qualquer modo, em muitas criticas e observações feitas aos artistas africanos, notava, por parte de estrangeiros e mesmo continentais, complexos quer de superioridade balofa quer de inferioridade bacoca. Havia preconceitos em todo o lado e a simples suavização do colonialismo operada no século anterior se
} 
revelava insuficiente para colocar as coisas em pratos equilibrados. Nem tudo era mau, infantil, grotesco, tosco, como advogavam criticos geralmente ocidentais, [...] (PEPETELA, 2017, p. 44).

No excerto, há exemplos de dialogicidade interna, uma resposta a um discurso já dito ou a um discurso futuro, presumivel. O primeiro exemplo está na relação entre as críticas feitas aos trabalhos dos africanos que revelam o olhar preconceituoso daquele que aprecia a obra, o estrangeiro, que considera o estilo africano como infantil e inferior. Um segundo exemplo de dialogicidade consiste no uso da expressão "suavização do colonialismo", aludindo ao fato de que Angola não se tornou efetivamente uma nação independente, tampouco equipara-se ao colonizador europeu. Percebe-se que os dois exemplos se estabelecem no discurso que está orientado para o ouvinte, ou seja, pertence a um diálogo entre falante (autor/narrador) e ouvinte (leitor).

Sofia, que "nunca cozinhou nem serviu a uma mesa" (PEPETELA, 2017, p. 27), torna-se sócia do restaurante em que trabalha como gerente há quatro anos e que punha "a funcionar sobre rodas de ouro, como dizia a Diego" (PEPETELA, 2017, p. 27). Dona Ester, sócia majoritária, é mãe de Ezequiel, um homem de trinta anos com problemas mentais, sem condições de trabalhar. A mãe paga dízimos vultosos à igreja (que agora já não é a católica), pois

há muito deixara de acreditar na capacidade dos médicos em entenderem o filho ou seus mecanismos secretos. Acreditava muito mais no pastor da igreja dela, que dizia, são demônios, só com muitas rezas e cultos aqui na igreja pode melhorar (PEPETELA, 2017, p. 24).

O restaurante é frequentado por um grupo da elite angolana que aprecia o cardápio criado por Sofia e consome bebidas caras, outra estratégia da jovem para aumentar o lucro do estabelecimento. Esse grupo representa a geração de "miúdos mimados" que, segundo Ricardo Soares de Oliveira (2015), são "os filhos de generais da FAA [Forças Armadas de Angola], em particular, [...] conhecidos pelo seu estilo de vida internacional, caracterizado pela devassidão e o consumismo"
(OLIVEIRA, 2015, p. 216). O professor Oliveira explica por que a elite se expõe somente no periodo de reconstrução do país:

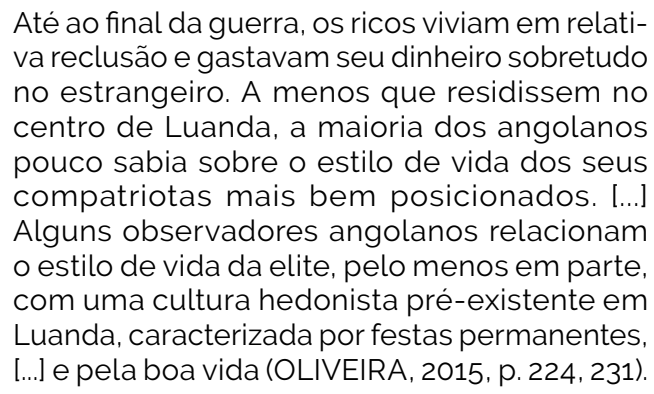

Na narrativa, Sofia aproxima-se dos clientes abastados, talvez com a ambição (ou a ilusão) de pertencer ao grupo; a jovem conquista a atenção de alguns rapazes e troca confidências com Salomé, a líder feminina das rodas de conversa: "De facto, não tens propensão para o suicídio, Sofia. Ainda tens ambições na vida. O que é bom. Se não forem demasiado desmedidas, se não te levarem a ultrapassar algumas barreiras..." (PEPETELA, 2017, p. 145)

A observação de Salomé antecipa aquela que será a atitude de Sofia após a morte súbita de Dona Ester: temendo a perda do restaurante, Sofia seduz e chantageia um funcionário do governo da província (recurso já empregado por Himba para ser aprovada em disciplina de seu curso de contabilidade) para tornar-se a sócia majoritária do estabelecimento. A jovem abre uma conta conjunta com Ezequiel, fazendo-o "imitar a assinatura que um dia escrevera no bilhete de identidade" (PEPETELA, 2017, p. 268) e transfere o rapaz para um lar de acolhimento, onde é impedido de receber visitas, exceto as dela e do irmão.

A atitude de Sofia alude à "herança da guerra", sendo "a corrupção, a especulação, o consumismo desenfreado, a perda de valores éticos e morais, o nepotismo, o interesse desmedido, além de outras vicissitudes" (VALENTIM, 2009, p. 348), reações justificáveis pelo passado de sofrimento. Para Oliveira (2015), "um dos fios condutores que percorre toda a história angolana é o desrespeito e até a crueldade dos poderosos em relação aos que não têm poder" (OLIVEIRA, 2015, p. 24). Sofia, portanto, 
para além do restaurante, herda as estratégias aprendidas nos tempos da guerra: coloca seus interesses acima de seus valores morais e éticos.

De uma posição externa, Diego dá-se conta do comportamento da amiga/irmã, que parece ter esquecido as injustiças e a violência do passado, repetindo os mesmos erros de seus opressores.

Também nunca vira tanto desgosto e nojo na cara dele.

- Ouve, mano. Eu ia te dizer, um desses dias. Mas só nos temos encontrado ao mata-bicho, há muito tempo não saimos juntos. E de manhã não é boa altura para se conversar.

- Qualquer altura é boa para falar sobre um assunto importante destes. Podias ter pedido a minha opinião. Não o fizeste. Sabias, eu ia dizer que estava errado, era só por ganância, não para ajudar o pobre do Ezequiel. Quando é que te tornaste assim, a pensar apenas no teu interesse? Essa não é a Himba que se tornou minha irmã Sofia... (PEPETELA, 2015, p. 351).

O cenário da guerra civil e das lutas no período pós-guerra constituem o espaço em que a personagem Himba/Sofia é construída. A personagem abandona paulatinamente a figura da menina ingênua e sofrida, recebida com empatia pelo leitor, e transforma-se em uma mulher inescrupulosa que almeja fundir-se à elite da sociedade angolana, apagando de vez o passado hediondo.

\section{Considerações finais}

Se o passado não tivesse asas estabelece, portanto, representa um processo dialógico que se completa na relação com o interlocutor, elemento fundamental e constitutivo do gênero, segundo Bakhtin (1988). A própria estrutura do romance de Pepetela, ao apresentar, simultaneamente, duas histórias que parecem independentes e distintas, evidencia o caráter não finalizável do discurso, o qual depende da participação ativa do interlocutor para completá-lo. Trata-se da relação inseparável entre a forma e o conteúdo do gênero que, juntos, propiciam a construção do sentido do texto. Uma narrativa nunca será conclusiva ou finalizável, mas estará sempre sujeita ao olhar externo do outro, tanto daquele que conta quanto daquele que lê ou ouve a história.

O grande diálogo proposto por Pepetela no romance em estudo denuncia, por meio das personagens Himba e Sofia, o passado violento das guerras e a tentativa inconcebivel de apagamento desse passado no atual processo de reconstrução de Angola.

\section{Referências}

AGUALUSA, José Eduardo. A literatura angolana e a representação da guerra pela independência, da guerra civil e da violência urbana. Revista Diversitas. Ano I, mar/ser, 2013. p.101-105. Disponivel em: http:// diversitas.fflch.usp.br/sites/diversitas.fflch.usp.br/files/ inline-files/Revista\%20Diversitas\%201.\%20Dossie\%20 Fronteiras\%20em\%20Movimento.pdf Acesso em: 18 fev. 2020.

BAKHTIN, Mikhail. Problemas da poética de Dostoiévski. Tradução direta do russo, notas e prefácio de Paulo Bezerra. 5.ed. Rio de Janeiro: Forense Universitária, 2015.

BAKHTIN, Mikhail. Questões de literatura e de estética: a teoria do romance. Tradução do russo de Aurora Fornoni Bernardini, José Pereira Júnior, Augusto Góes Júnior, Helena Spryndis Nazário e Homero Freitas de Andrade. São Paulo: Hucitec, 1988.

BAKHTIN, Mikhail. The dialogic imagination: four essays by M.M. Bakhtin. Editado por Michael Holquist. Tradução para o inglês de Caryl Emerson e Michael Holquist. Austin: University of Texas Press, 1981.

BEATON, Roderick. Poética histórica: cronotopos em Leucipe e Clitofonte e Tom Jones. Tradução de Lásaro José Amaral. In: BEMONG, Nele et al. (org.). Bakhtin e o cronotopo: reflexões, aplicações, perspectivas. São Paulo: Parábola Editorial, 2015, p. 80-98.

EMERSON, Caryl. Os cem primeiros anos de Mikhail Bakhtin. Tradução de Pedro Jorgensen Jr. Rio de Janeiro: DIFEL, 2003.

GENETTE, Gérard. Discurso da narrativa. 3. ed. Lisboa: Veja, 1995.

HUTCHEON, Linda. Poética do pós-modernismo história, teoria, ficção. Tradução de Ricardo Cruz. Rio de Janeiro: Imago Editora, 1988.

MORSON, Gary Saul \& EMERSON, Caryl. Mikhail Bakhtin: criação de uma prosaística. Tradução de Antonio Pádua Danesi. São Paulo: Editora da Universidade de São Paulo, 2008.

OLIVEIRA, Ricardo Soares de. Magnífica e miserável: Angola desde a guerra civil. Tradução de Suzana Souza e Silva. Lisboa: Tinta da China, 2015

PEPETELA. Pepetela por Inocência Mata. [Entrevista cedida al Inocência Mata. Camões - Revista de Letras e Culturas Lusófonas. Lisboa, n. 6, set. 1999. p. 113-116. Disponivel em: file:///C:/Users/usuario/Downloads/ rev6_art14_pepetela.pdf Acesso em: 20 fev. 2020.

PEPETELA. Se o passado não tivesse asas. Rio de Janeiro, LeYa, 2017. 
SECCO, Carmen Lucia Tindó Ribeiro. Na curva oblonga do tempo, uma alegórica parábola... In: CHAVES, Rita; MACÊDO, Tania (org.). Portanto... Pepetela. São Paulo: Ateliê Editorial, 2009. p. 151-169.

VALENTIM, Jorge. Pepetela e a predatória arte de narra. In: CHAVES, Rita; MACÊDO, Tania (org.). Portanto...

Pepetela. São Paulo: Ateliê Editorial, 2009. p. 347-355.

Ana Maria Coelho Silva Wertheimer

Doutora em Teoria da Literatura pela Pontificia Universidade Católica do Rio Grande do Sul (PUCRS), em Porto Alegre, Brasil; professora do curso de Graduação em Letras da mesma instituição.

\section{Endereço de correspondência}

Ana Maria Coelho Silva Wertheimer

Escola de Humanidades da Pontificia Universidade Católica do Rio Grande do Sul (PUCRS).

Av. Ipiranga, 6681, Prédios 8 e 9

Partenon - Porto Alegre/RS - CEP: 90619-900 